\title{
Working the Night Shift: The Impact of Compensating Wages and Local Economic Conditions on Shift Choice
}

\author{
Colene Trent $^{1}$ and Walter J. Mayer $^{2}$ \\ ${ }^{1}$ Department of Business Administration, McAfee School of Business Administration, Union University, 1050 Union University Drive, \\ Jackson, TN 38305, USA \\ ${ }^{2}$ Department of Economics, University of Mississippi, 342 Holman Hall, University, MS 38677, USA
}

Correspondence should be addressed to Colene Trent; ctrent@uu.edu

Received 26 July 2014; Accepted 24 September 2014; Published 9 October 2014

Academic Editor: Arjun S. Bedi

Copyright (c) 2014 C. Trent and W. J. Mayer. This is an open access article distributed under the Creative Commons Attribution License, which permits unrestricted use, distribution, and reproduction in any medium, provided the original work is properly cited.

The theory of compensating differentials asserts that night shift workers should receive compensating wage differentials due to undesirable work conditions. In weak local economies, workers may have difficulty finding jobs; thus, these workers might be more likely to accept night shift work and be less concerned with the size of the compensating differential for night shifts. Using CPS data from 2001, this paper employs maximum likelihood estimation of an endogenous switching regression model to analyze wages of day and night shift workers and shift choice. The findings indicate the presence of selection bias, thus emphasizing the importance of correcting for self-selection into night shifts. The average of the estimated wage differentials for night shift work is negative for the overall sample, with differentials varying by worker characteristics. The shift differential is found to be a statistically significant predictor of shift choice, indicating that shift premiums play an important role in motivating individuals to select night shift work. Using two measures of local economic conditions and a new method of analyzing interaction effects in the context of an endogenous switching regression model, this paper finds limited evidence that weak local economic conditions lessen the impact of compensating differentials on shift choice.

\section{Introduction}

Smith [1] first proposed the idea that working conditions could impact wages and worker preferences for jobs. The theory of compensating differentials as described by Rosen [2] refers to the idea that wage differentials equalize the total monetary and nonmonetary advantages and disadvantages among work activities and among workers themselves. This theory assumes that workers can easily find jobs with desirable characteristics; thus, compensating wages are necessary to induce workers to take jobs with undesirable characteristics. This paper considers a variation of the theory of compensating differentials in which labor markets are weak and workers have difficulty finding jobs. In weak economies, employers have the advantage of a larger number of potential employees and workers are more likely to take jobs that would otherwise be undesirable. Poor economic conditions may thus lower the compensating wage differential offered for undesirable work conditions.
One job characteristic for which compensating differentials may arise is work-time scheduling, including night shift work. Night shift workers have what could arguably be considered the most undesirable work schedule; thus it has been hypothesized that one reason workers are motivated to select night shift work is to receive the compensating wage differential. However, in areas with weak local economic conditions where jobs are relatively scarce, the compensating wage differential may be less of a motivating factor for selecting night shift work. Compensating wage differentials are commonly analyzed using wage regressions, with worker wages modeled as a function of worker and job characteristics. This paper uses a more general econometric model, an endogenous switching regression model (ESR), to analyze not only compensating wages, but also selection into night shift work, with night shift selection modeled as a function of worker and job characteristics, night shift differentials, and local economic conditions. The focus of this paper is twofold, to determine the impact of wage differentials and local 
economic conditions on shift selection and to determine how the impact of the night wage differential on shift selection depends upon local economic conditions.

Kostiuk [3] and Lanfranchi, et al. [4] (For other shiftwork related studies, see Schumacher and Hirsch [5] and Agnarsson [6].) provide the most widely cited research on shift differentials, employing two-step estimation of ESR models to find positive wage differentials for shift workers. DeBeaumont and Nsiah [7] employ a treatment effects model to estimate night shift differentials. They additionally examine the impact of the interaction between the unemployment rate and one's status as a night shift worker upon worker wages, with results suggesting that compensating wages for working night shifts are relatively smaller in areas with higher unemployment. Although not a study of shift workers, Bender and Mridha [8] study the impact of local unemployment on compensating wages for injury on the job. They determine that estimated compensating wage differentials for injury risk are lower in areas of high unemployment.

This paper builds upon the work of Kostiuk and Lanfranchi et al. by including indicators of labor market strength, the local unemployment rate, and the state coincident index, in our analysis. Additionally, our analysis is the first shift work-related study to employ maximum likelihood estimation of an endogenous switching regression (ESR) model. This paper builds upon the work of DeBeaumont and Nsiah [7] and Bender and Mridha [8] by using the more general ESR model, which allows for the estimation of the effect of wage differentials and local economic conditions on the decision to work a night shift and allows the returns to individual characteristics of day and night workers to differ. Additionally the model is analyzed using the state coincident index as an alternate measure of local economic conditions. In order to determine how the impact of the night wage differential on shift selection depends upon local economic conditions, we analyze the interaction effect between shift differentials and local economic conditions on shift choice. Evaluating and interpreting interaction effects are complicated in the ESR model because the interaction depends on correlation between night and day shift wages which is not point identified. This paper offers a new method of investigating interaction effects by estimating lower and upper bounds on the probability of selecting night shift work for different values of the shift differential and the local economic conditions.

\section{Theoretical Specification and Estimation Strategy}

A basic approach to measure the impact of night shift work on wages would be to assign a dummy indicator variable for night shift work and include it as a right hand side variable in a regression of wages on worker characteristics. A simple hedonic log wage version of the model would thus take the following form:

$$
w_{i}=\alpha+\beta_{1} X_{i}+\beta_{2} n s h i f t_{i}+\varepsilon_{i}
$$

where the dependent variable is the log of the individual's wage, $X$ is a vector of personal characteristics, nshift is a dummy variable indicating whether or not an individual works a night shift, and $\varepsilon$ is an iid error term. In this model, $\beta_{2}$ is an estimate of the compensating differential for night shift work. To allow the differential to vary with local economic conditions, a measure of local economic conditions, LEC, and their interaction with nshift is added to (1) as follows:

$$
w_{i}=\alpha+\beta_{1} X_{i}+\beta_{2} \text { nshift }_{i}+\beta_{3} L_{E C_{i}}+\text { Anshift }_{i} L E C_{i}+\varepsilon_{i} .
$$

In the empirical section of the paper, LEC are specified as either the local unemployment rate or the one month percentage change in the state coincident index. In (2), $\beta_{2}$ indicates the compensating differential for night shift work when the local unemployment rate or the one month percentage change in the state coincident index is zero. The coefficient $\theta$ indicates how the compensating differential for night shift work changes when local economic conditions change. If compensating differentials for night shift work are lower in areas with weak economic conditions, then $\theta$ will be negative when the local unemployment rate is specified for $L E C$ and positive when the percentage change in the state coincident index is specified for $L E C$.

OLS estimates of the above equations are biased and inconsistent due to the endogeneity of the night shift variable. An individual's status as a night shift worker is likely correlated with variables in the error term of the wage equation. Worker characteristics such as ability, schedule constraints, preferences, and family obligations are unmeasured components of the wage that are likely correlated with the decision to work a night shift. This endogeneity is a form of selection bias. To correct for it, we will adopt an ESR model. A general discussion of the ESR model can be found in Maddala [9], for example. The model is described in detail in the next section. In the ESR model, separate equations are specified for day and night shift wages, and individuals self-select into either day work or night work according to a selection equation specified for the decision to work the night shift. The selection equation depends on the difference between day and night shift wages, and the error term in the selection equation can be correlated with the error terms of the wage equations. Consequently, wages and the decision to work the night shift are jointly determined in the ESR model. Following Maddala [9] (The ESR model may also be estimated by a two-step estimator employed by Lee [10] who applies the model to the wages of union and nonunion workers. Although computationally simpler, the two-step estimator is less efficient than FIML.), the ESR model is estimated using full information maximum likelihood (FIML). The FIML estimates are consistent and asymptotically efficient.

2.1. Equations Used in the Switching Regression Model. In the ESR model, separate log wage equations for night and day workers are assumed to take the following form:

$$
\begin{aligned}
& w_{i}^{n}=X_{i} \beta^{n}+\operatorname{LEC}_{i} \theta^{n}+\varepsilon_{i}^{n}, \\
& w_{i}^{d}=X_{i} \beta^{d}+L E C_{i} \theta^{d}+\varepsilon_{i}^{d},
\end{aligned}
$$


where the dependent variable is the log hourly wage rate for individuals and $X$ is a vector of personal, demographic, occupational, and industrial variables. LEC denote the local economic conditions, as measured by either the local unemployment rate or the one month percentage change in the state coincident index. Equation (3) models wages for night shift work (denoted by the superscript $n$ ), and (4) models wages for day workers (denoted by the superscript $d$ ). These equations allow the returns to each worker characteristic to be different for night and day workers. Since workers choose which shift to work, a structural selection equation specifying shift choice is also included in the model. Shift choice is determined by

$$
S_{i}^{*}=Z_{i} \gamma_{1}+L E C_{i} \gamma_{2}+\delta\left(w_{i}^{n}-w_{i}^{d}\right)+v_{i}
$$

where $S_{i}^{*}$ denotes the net benefit of working a night shift. The value of $S^{*}$ is not observed, only whether it is positive (night shift chosen) or negative (night shift not chosen). The latter is coded by the zero-one indicator function:

$$
s_{i}=I\left(s_{i}^{*} \geq 0\right) \text {. }
$$

The observed log wage can thus be written as

$$
w_{i}=s_{i} w_{i}^{n}+\left(1-s_{i}\right) w_{i}^{d}
$$

In (5), $Z$ denotes a vector of variables that influence shift choice. Identification requires that $Z$ includes at least one variable not contained in $X$. The variable $\left(w_{i}^{n}-w_{i}^{d}\right)$ is the premium obtained for night shift work. The unobserved errors $\left(\varepsilon_{i}^{n}, \varepsilon_{i}^{d}, v_{i}\right)$ are assumed to be distributed independently of $(X, Z, L E C)$ and trivariate normal:

$$
\left(\begin{array}{c}
\varepsilon_{i}^{n} \\
\varepsilon_{i}^{d} \\
v_{i}
\end{array}\right) \sim N\left[\left(\begin{array}{l}
0 \\
0 \\
0
\end{array}\right),\left(\begin{array}{ccc}
\sigma_{n}^{2} & \sigma_{n d} & \sigma_{n v} \\
\sigma_{n d} & \sigma_{d}^{2} & \sigma_{d v} \\
\sigma_{n v} & \sigma_{d v} & 1
\end{array}\right)\right] .
$$

The wage equations (3) and (4) and the selection equation (5) form the endogenous switching regression model. The error terms in the individual's wage equations, $\varepsilon_{i}^{n}$ and $\varepsilon_{i}^{d}$, are likely correlated with the error term in the selection equation, $v_{i}$, which is a source of selection bias. By substituting (3) and (4) into (5) we obtain the reduced form as follows:

$$
\begin{aligned}
S_{i}^{*}= & Z_{i} \gamma_{1}+L E C_{i} \gamma_{2}+\delta X_{i}\left(\beta^{n}-\beta^{d}\right) \\
& +\delta L E C_{i}\left(\theta^{n}-\theta^{d}\right)+\delta\left(\varepsilon_{i}^{n}-\varepsilon_{i}^{d}\right)+v_{i},
\end{aligned}
$$

which can be written as

$$
S_{i}^{*}=Z_{i} \gamma_{1}+X_{i} \pi_{1}+L E C_{i} \pi_{2}+\eta_{i}
$$

Since only the sign of $S^{*}$ is observable, the coefficients of (5) and (10) are only identified up to scale. As with (5), we resolve this by adopting the standard (and innocuous) normalization, $\operatorname{var}\left(\eta_{i}\right)=1$.
2.2. Maximum Likelihood Estimation. Full information maximum likelihood (Lokshin and Sajaia [11] provide a STATA program, movestay, for maximum likelihood estimation of the endogenous switching regression model.) estimation of the ESR model entails jointly estimating the parameters (3), (4), and (10) under assumption (8). The likelihood function has the following form:

$$
\begin{aligned}
L=\prod_{i=1}^{n}\left[S \int_{-\psi}^{\infty} f_{\varepsilon^{n}, \eta}\left(W_{i}-X_{i} \beta^{n}-L E C_{i} \theta^{n}, \eta\right) d \eta\right. \\
\left.\quad+(1-S) \int_{-\infty}^{-\psi} f_{\varepsilon^{d}, \eta}\left(W_{i}-X_{i} \beta^{d}-L E C_{i} \theta^{d}, \eta\right) d \eta\right],
\end{aligned}
$$

where $\psi=Z_{i} \gamma_{1}+X_{i} \pi_{1}+L E C_{i} \pi_{2} \cdot f_{\left(\varepsilon^{n}, \eta\right)}$ and $f_{\left(\varepsilon^{d}, \eta\right)}$ are the bivariate normal density functions of $\left(\varepsilon^{n}, \eta\right)$ and $\left(\varepsilon^{d}, \eta\right)$.

The estimates of (3), (4), and (10) computed by maximizing (11) can then be used to derive the estimates of the structural parameters of (5) and covariances in (8). The estimates of the covariances provide a basis for testing for the presence of selection bias and indicate whether the selection bias is positive or negative. (The results generated by the Stata program movestay include estimates of the correlation coefficient between the error term in each wage equation and the selection equation $\left(\rho_{\varepsilon^{n}, \eta}\right.$ and $\left.\rho_{\varepsilon^{d}, \eta}\right)$ and the standard deviation of the errors in the wage equations $\left(\sigma_{\varepsilon^{n}}\right.$ and $\left.\sigma_{\varepsilon^{d}}\right)$. The selection term coefficients, estimates of the covariance between the errors, are obtained by multiplying the correlation coefficients by the standard deviations from each individual wage equation. Using the night shift selection term as an example, since $\sigma_{\varepsilon^{n}, \eta}=\sigma_{\varepsilon^{n}} \rho_{\varepsilon^{n}, \eta} \sigma_{\eta}$ where $\sigma_{\eta}$ is normalized to 1 , multiplying $\sigma_{\mathcal{E}^{n}}$ by $\rho_{\mathcal{E}^{n}, \eta}$ provides an estimate of the covariance. Since $\sigma_{\varepsilon^{n}}$ is a scale factor, the significance of $\rho_{\varepsilon^{n}, \eta}$ and $\rho_{\varepsilon^{d} \eta}$ determines the presence of significant selection into a night or day work schedule.)

2.3. Interaction Effects. In the OLS specification (2), the coefficient of the interaction term indicates how the compensating differential for night shift work changes when local economic conditions change. The use and interpretation of interaction terms are more complicated in the ESR model. Analyzing the impact of local economic conditions on shift differentials is accomplished in the ESR by analyzing the impact of the interaction between the shift differential and local economic conditions on the probability that the night shift is selected. This analysis will help to answer a major question addressed by this paper: how does the impact of the shift differential on shift selection depend on local economic conditions? In areas with weak economic conditions, we might expect shift selection to depend less on the night shift differential since workers would likely have fewer alternatives to night shift work and more unemployed workers would be competing for shift positions. Night shift work is also less likely to be profitable in weak economies when production levels are down, and thus fewer shift positions are likely to be available. Consequently, a greater supply of shift workers coupled with lower demand for them means that firms can pay a smaller shift differential. 
To investigate this possible interaction, we consider the probability of selecting night shift work conditional on the shift differential, local economic conditions and the observed exogenous covariates. It follows from (3) through (7) and well-known properties of the multivariate normal distribution that

$$
\begin{aligned}
& P\left(s_{i}=1 \mid w_{i}^{n}-w_{i}^{d}, L E C_{i}, X_{i}, Z_{i}\right) \\
& \quad=1-\Phi\left[\frac{-\mu\left(w_{i}^{n}-w_{i}^{d}, L E C_{i}, X_{i}, Z_{i}\right)}{\sqrt{\operatorname{var}\left(s_{i}^{*} \mid L E C_{i}, X_{i}, Z_{i}\right)\left(1-\rho^{2}\right)}}\right],
\end{aligned}
$$

where $\Phi$ denotes the standard normal distribution function and

$$
\begin{aligned}
& \mu\left(w_{i}^{n}-w_{i}^{d}, L E C_{i}, X_{i}, Z_{i}\right) \\
& =E\left(s_{i}^{*} \mid L E C_{i}, X_{i}, Z_{i}\right) \\
& +\rho \sqrt{\frac{\operatorname{var}\left(s_{i}^{*} \mid L E C_{i}, X_{i}, Z_{i}\right)}{\operatorname{var}\left(w_{i}^{n}-w_{i}^{d} \mid L E C_{i}, X_{i}, Z_{i}\right)}} \\
& \times\left(w_{i}^{n}-w_{i}^{d}-E\left(w_{i}^{n}-w_{i}^{d} \mid L E C_{i}, X_{i}, Z_{i}\right)\right), \\
& E\left(s_{i}^{*} \mid L E C_{i}, X_{i}, Z_{i}\right) \\
& =Z_{i} \gamma_{1}+L E C_{i} \gamma_{2}+\delta E\left(w_{i}^{n}-w_{i}^{d} \mid L E C_{i}, X_{i}, Z_{i}\right), \\
& E\left(w_{i}^{n}-w_{i}^{d} \mid L E C_{i}, X_{i}, Z_{i}\right) \\
& =X_{i}\left(\beta^{n}-\beta^{d}\right)+L E C_{i}\left(\theta^{n}-\theta^{d}\right) \text {, } \\
& \rho=\frac{\operatorname{cov}\left(s_{i}^{*}, w_{i}^{n}-w_{i}^{d} \mid L E C_{i}, X_{i}, Z_{i}\right)}{\sqrt{\operatorname{var}\left(w_{i}^{n}-w_{i}^{d} \mid L E C_{i}, X_{i}, Z_{i}\right) \operatorname{var}\left(s_{i}^{*} \mid L E C_{i}, X_{i}, Z_{i}\right)}}, \\
& \operatorname{var}\left(s_{i}^{*} \mid L E C_{i}, X_{i}, Z_{i}\right) \\
& =\delta^{2} \operatorname{var}\left(w_{i}^{n}-w_{i}^{d} \mid L E C_{i}, X_{i}, Z_{i}\right)+1+2\left(\sigma_{n v}-\sigma_{d v}\right) \text {, } \\
& \operatorname{cov}\left(s_{i}^{*}, w_{i}^{n}-w_{i}^{d} \mid L E C_{i}, X_{i}, Z_{i}\right) \\
& =\delta \operatorname{var}\left(w_{i}^{n}-w_{i}^{d} \mid L E C_{i}, X_{i}, Z_{i}\right)+\sigma_{n v}-\sigma_{d v}, \\
& \operatorname{var}\left(w_{i}^{n}-w_{i}^{d} \mid L E C_{i}, X_{i}, Z_{i}\right)=\sigma_{n}^{2}+\sigma_{d}^{2}-2 \sigma_{n d} .
\end{aligned}
$$

Of interest is the effect of changes in the shift differential on the probability of selecting night shift work (12) under different local economic conditions. One obstacle is that (12) depends on $\sigma_{n d}$ which is not point identified and, therefore, neither is (12). Both quantities are only partially identified. Vijverberg [12] provides informative bounds for $\sigma_{n d}$ that can be consistently estimated, but deriving informative bounds for (12) from these is complicated by the fact that (12) is not a monotonic function of $\sigma_{n d}$ for all values of the shift differential. However, (12) is a monotonic function of $\sigma_{n d}$ when conditioned on the expected differential, that is, $w_{i}^{n}-$
$w_{i}^{d}=E\left(w_{i}^{n}-w_{i}^{d} \mid L E C_{i}, X_{i}, Z_{i}\right)$, and, thus, deriving informative bounds in this case is a straightforward exercise. (For the other cases, it would be necessary to apply constrained minimization and maximization techniques to (12) over the bounds interval for $\sigma_{n d}$ to derive the bounds.) A focus on the expected differential can also be justified by being the "average" shift differential for the subset of the population characterized by the given values of $X, Z$, and LEC. Hence, we will investigate how the effect of the shift differential on the distribution of shift selection depends on local economic conditions by analyzing changes in the expected differential for various local economic conditions. The lower and upper bounds of the selection probability are given by Theorem 1 .

Theorem 1. If $w_{i}^{n}-w_{i}^{d}=E\left(w_{i}^{n}-w_{i}^{d} \mid L E C_{i}, X_{i}, Z_{i}\right)$ then $B_{L} \leq P\left(s_{i}=1 \mid w_{i}^{n}-w_{i}^{d}, L E C_{i}, X_{i}, Z_{i}\right) \leq B_{U}$ where $B_{L}=$ $1-\Phi\left(\left(-E\left(s_{i}^{*} \mid L E C_{i}, X_{i}, Z_{i}\right)\right) / \sqrt{\Lambda_{L}}\right)$ and $B_{U}=1-\Phi\left(\left(-E\left(s_{i}^{*} \mid\right.\right.\right.$ $\left.\left.\left.L E C_{i}, X_{i}, Z_{i}\right)\right) / \sqrt{\Lambda_{U}}\right)$.

Let

$$
\begin{aligned}
\Lambda_{L}= & \Lambda_{2} I\left[E\left(s_{i}^{*} \mid L E C_{i}, X_{i}, Z_{i}\right) \geq 0\right] \\
& +\Lambda_{1} I\left[E\left(s_{i}^{*} \mid L E C_{i}, X_{i}, Z_{i}\right)<0\right], \\
\Lambda_{U}= & \Lambda_{2} I\left[E\left(s_{i}^{*} \mid L E C_{i}, X_{i}, Z_{i}\right)<0\right] \\
& +\Lambda_{1} I\left[E\left(s_{i}^{*} \mid L E C_{i}, X_{i}, Z_{i}\right) \geq 0\right],
\end{aligned}
$$

where

$$
\begin{gathered}
\Lambda_{1}=1+2(1-\delta)\left(\sigma_{n v}-\sigma_{d v}\right)-\frac{\left(\sigma_{n v}-\sigma_{d v}\right)^{2}}{\sigma_{n}^{2}+\sigma_{d}^{2}-2\left(\sigma_{n v} \sigma_{d v}+c\right)} \\
\Lambda_{2}=1+2(1-\delta)\left(\sigma_{n v}-\sigma_{d v}\right)-\frac{\left(\sigma_{n v}-\sigma_{d v}\right)^{2}}{\sigma_{n}^{2}+\sigma_{d}^{2}-2\left(\sigma_{n v} \sigma_{d v}-c\right)} \\
c=\sigma_{n} \sigma_{v} \sqrt{\left(1-\left(\frac{\sigma_{n v}}{\sigma_{n}}\right)^{2}\right)\left(1-\left(\frac{\sigma_{d v}}{\sigma_{v}}\right)^{2}\right)} .
\end{gathered}
$$

Proof. Given $w_{i}^{n}-w_{i}^{d}=E\left(w_{i}^{n}-w_{i}^{d} \mid L E C_{i}, X_{i}, Z_{i}\right)$, it follows from (12) that

$$
\begin{aligned}
P & \left(s_{i}=1 \mid w_{i}^{n}-w_{i}^{d}, L E C_{i}, X_{i}, Z_{i}\right) \\
& =1-\Phi\left[\frac{-E\left(s_{i}^{*} \mid L E C_{i}, X_{i}, Z_{i}\right)}{\sqrt{\operatorname{var}\left(s_{i}^{*} \mid L E C_{i}, X_{i}, Z_{i}\right)\left(1-\rho^{2}\right)}}\right],
\end{aligned}
$$

where

$$
\begin{aligned}
\operatorname{var}\left(s_{i}^{*} \mid L E C_{i}, X_{i}, Z_{i}\right)\left(1-\rho^{2}\right) \\
\quad=1+2(1-\delta)\left(\sigma_{n v}-\sigma_{d v}\right)-\frac{\left(\sigma_{n v}-\sigma_{d v}\right)^{2}}{\sigma_{n}^{2}+\sigma_{d}^{2}-2 \sigma_{n d}} .
\end{aligned}
$$

By Vijverberg ([12], page 71), consider

$$
\sigma_{n v} \sigma_{d v}-c \leq \sigma_{n d} \leq \sigma_{n v} \sigma_{d v}+c,
$$

and, therefore, $-2\left(\sigma_{n v} \sigma_{d v}-c\right) \geq-2 \sigma_{n d} \geq-2\left(\sigma_{n v} \sigma_{d v}+c\right)$. 
The lower and upper bounds of the selection probability in Theorem 1 are functions of only the identified parameters and thus can be consistently point-estimated for any specified setting of $L E C_{i}, X_{i}, Z_{i}, E\left(w_{i}^{n}-w_{i}^{d} \mid L E C_{i}, X_{i}, Z_{i}\right)$. The estimated bounds are discussed further in Section 4.2.

\section{Data}

This paper employs survey data from the Current Population Survey (CPS) which is a monthly survey of approximately 50,000 households conducted by the Bureau of Labor Statistics (BLS). Supplementary questionnaires in some months ask respondents about other topics such as health, school enrollment, and work schedules. This paper uses crosssectional individual-level data from one of those special supplements, the May 2001 CPS Work Schedules Supplement, which asks questions related to shift work [13].

Demographic Data. Wage and demographic information are taken from the CPS to produce a sample of full-time civilian workers. (CPS observations which have imputed earnings were deleted from the data used in this study because of the biases noted in Bollinger and Hirsch [14]. Leaving in the imputed earnings does not cause a notable difference in regression coefficients but has a more notable impact on the calculated wage differentials. For workers paid by the hour, the May CPS directly reports the hourly rate of pay. For other workers, we compute an hourly wage rate by dividing usual weekly earnings by usual weekly hours of work. Following the literature, we adjust for topcoding of wages by multiplying topcoded wages by a factor of 1.4. Workers with wages less than $\$ 1$ and more than $\$ 100$ an hour are dropped from the dataset, as well as workers below the age of sixteen and above the age of sixty-five. Workers with negative potential work experience are also dropped from the sample. Full-time workers are those working at least 30 hours per week.) Controls used in the wage regressions are standard in the literature: education, experience, gender, marital status, union membership, race, region of residence, and indicators for occupation, industry, and metropolitan statistical area residence. Table 1 provides summary statistics for each variable for all observations used in the regressions.

Shift Status. Shifts defined by the CPS are day, evening, night, rotating, split, irregular, or other shifts. The BLS defines a regular day shift as one that takes place between the hours of 6 a.m. and 6 p.m. Evening shifts usually occur between the hours of 2 p.m. and midnight. A night shift is defined as a shift schedule taking place between the hours of 9 p.m. and 8 a.m. Rotating shifts require that workers rotate through a cycle of shifts, that is, working first day shifts and then evening shifts and then night shifts. On a split shift schedule, individuals work during two distinct periods each day. Individuals working irregular shifts do not have a predetermined regular shift schedule. For example, they may work night shifts one week, day shifts the next week, and then possibly night shifts again the next week. In the full CPS sample of civilian workers for May 2001, 82.6\% of workers worked day shifts, $6.4 \%$ worked evening shifts, and $2.9 \%$ worked night shifts. $2.3 \%, 0.5 \%, 4.4 \%$, and $0.7 \%$ of the sample worked rotating, split, irregular, and other shifts, respectively.

Following the research of DeBeaumont and Nsiah [7], the two categories of workers considered for the current analysis are regular day shift and regular night shift. The rationale for choosing to compare day workers to night workers rather than comparing day workers to all workers who are employed during nonstandard hours follows the research of Schumacher and Hirsch [5], Shapiro [15], Mayshar and Solon [16], and Halevy and Nason [17]. Schumacher and Hirsch [5] indicate larger wage premiums for night shift nurses relative to those working evening shifts, split shifts, rotating shifts, or other shifts. This finding is consistent with the theory of compensating differentials. Night shift work is likely seen as a more inconvenient work schedule when compared to other schedules; thus, compensating wages are likely to be more prevalent in night shifts.

Local Economic Conditions (Unemployment Rate and Coincident Index). This paper also seeks to determine the impact of local economic conditions on the size of the compensating wage differential for shift work and on the incidence of shift work. This further justifies the use of day versus night shifts. Shapiro [15] and Mayshar and Solon [16] provide evidence of the cyclical nature of shiftwork. Mayshar and Solon indicate that night shift employment is more responsive to changes in real GNP than overall employment. Halevy and Nason [17] also find that night shift employment is extremely procyclical. The current analysis is restricted to a comparison of day and night shift workers since differences in compensating wages and the effect of changes in local economic conditions will be more pronounced. The summary statistics provided in Table 1 indicate that $3.7 \%$ of the sample worked night shifts.

The May 2001 CPS supplement was used for the analysis. This marked the beginning of an economic downturn. After a decade of economic growth during the 1990s, the U.S. economy began to falter. Kliesen [18] cites "the boom and bust in U.S. equity markets, the sharp decline in business capital expenditures for computers and software, the economic fallout from the events surrounding September 11, and the significant decline in the real value of U.S. exports" as factors that likely contributed to the recession of 2001, which lasted from March through November. Although the 2001 recession was relatively mild, the unemployment rate continued to rise for 19 months following the end of the recession [19]. Using data from the 2001 CPS supplement provides an opportunity to analyze night shift wages and night shift choice during a weakened economy.

The unemployment rate used in the analysis is defined as the local unemployment rate at the labor market of current residence. A separate sample is taken from the CPS for 2001 that includes both working and unemployed individuals. From this sample, we calculate unemployment rates at the metropolitan statistical area (MSA) and state level. MSA unemployment rates are used for workers who reside in an MSA, while the state unemployment rate is used for rural workers.

This paper also uses the state coincident index as another indicator of local economic conditions. The coincident index 
TABLE 1: Summary statistics by variable.

\begin{tabular}{|c|c|c|c|c|}
\hline Variable & Description & All & Day & Night \\
\hline Wage & Hourly wage in dollars and cents & $\begin{array}{c}17.754 \\
(11.165)\end{array}$ & $\begin{array}{c}17.908 \\
(11.303)\end{array}$ & $\begin{array}{l}13.795 \\
(5.391)\end{array}$ \\
\hline Log wage & Logarithm of hourly wage & $\begin{array}{c}2.724 \\
(0.539)\end{array}$ & $\begin{array}{c}2.731 \\
(0.543)\end{array}$ & $\begin{array}{c}2.547 \\
(0.401)\end{array}$ \\
\hline Night shift & $=1$ if night shift worker & $\begin{array}{c}0.037 \\
(0.190)\end{array}$ & & \\
\hline Years of school & Years of completed schooling & $\begin{array}{l}13.598 \\
(2.463)\end{array}$ & $\begin{array}{l}13.628 \\
(2.481)\end{array}$ & $\begin{array}{l}12.834 \\
(0.178)\end{array}$ \\
\hline Experience & Age-hgc-6 & $\begin{array}{c}21.422 \\
(10.150)\end{array}$ & $\begin{array}{l}21.468 \\
(10.115)\end{array}$ & $\begin{array}{c}20.245 \\
(10.970)\end{array}$ \\
\hline Union & $=1$ if wages are set by collective bargaining & $\begin{array}{c}0.154 \\
(0.361)\end{array}$ & $\begin{array}{c}0.151 \\
(0.358)\end{array}$ & $\begin{array}{c}0.218 \\
(0.415)\end{array}$ \\
\hline Nonwhite & $=1$ if nonwhite & $\begin{array}{c}0.134 \\
(0.340)\end{array}$ & $\begin{array}{c}0.132 \\
(0.338)\end{array}$ & $\begin{array}{c}0.185 \\
(0.390)\end{array}$ \\
\hline Female & $=1$ if female & $\begin{array}{c}0.492 \\
(0.500)\end{array}$ & $\begin{array}{c}0.494 \\
(0.500)\end{array}$ & $\begin{array}{c}0.43 \\
(0.497)\end{array}$ \\
\hline Married & $=1$ if married & $\begin{array}{c}0.851 \\
(0.356)\end{array}$ & $\begin{array}{c}0.854 \\
(0.353)\end{array}$ & $\begin{array}{c}0.788 \\
(0.410)\end{array}$ \\
\hline Northeast & $=1$ if resident of northeast & $\begin{array}{c}0.183 \\
(0.387)\end{array}$ & $\begin{array}{c}0.184 \\
(0.388)\end{array}$ & $\begin{array}{c}0.146 \\
(0.354)\end{array}$ \\
\hline North Central & $=1$ if resident of north central & $\begin{array}{c}0.259 \\
(0.439)\end{array}$ & $\begin{array}{c}0.26 \\
(0.439)\end{array}$ & $\begin{array}{c}0.258 \\
(0.439)\end{array}$ \\
\hline South & $=1$ if resident of south & $\begin{array}{c}0.292 \\
(0.455)\end{array}$ & $\begin{array}{c}0.291 \\
(0.454)\end{array}$ & $\begin{array}{c}0.305 \\
(0.462)\end{array}$ \\
\hline MSA & $=1$ if resident of a metropolitan statistical area & $\begin{array}{c}0.718 \\
(0.450)\end{array}$ & $\begin{array}{c}0.72 \\
(0.449)\end{array}$ & $\begin{array}{c}0.662 \\
(0.474)\end{array}$ \\
\hline Children present & $=1$ if respondent has children & $\begin{array}{c}0.598 \\
(0.490)\end{array}$ & $\begin{array}{c}0.596 \\
(0.491)\end{array}$ & $\begin{array}{c}0.649 \\
(0.479)\end{array}$ \\
\hline Industry shift rate & $\begin{array}{l}\text { Shift rate within the industry, calculated as the proportion } \\
\text { of night shift workers in } 234 \text { detailed industry categories }\end{array}$ & $\begin{array}{c}2.896 \\
(3.507)\end{array}$ & $\begin{array}{c}2.725 \\
(3.362)\end{array}$ & $\begin{array}{c}7.292 \\
(4.226)\end{array}$ \\
\hline Multiple jobs & $=1$ if respondent works multiple jobs & $\begin{array}{c}0.059 \\
(0.236)\end{array}$ & $\begin{array}{c}0.058 \\
(0.234)\end{array}$ & $\begin{array}{c}0.093 \\
(0.291)\end{array}$ \\
\hline Wholesale trade industry & $=1$ if wholesale trade industry & $\begin{array}{c}0.045 \\
(0.208)\end{array}$ & $\begin{array}{c}0.046 \\
(0.210)\end{array}$ & $\begin{array}{c}0.02 \\
(0.140)\end{array}$ \\
\hline Retail trade industry & $=1$ if retail trade industry & $\begin{array}{c}0.097 \\
(0.296)\end{array}$ & $\begin{array}{c}0.093 \\
(0.291)\end{array}$ & $\begin{array}{c}0.179 \\
(0.384)\end{array}$ \\
\hline Transportation industry & $=1$ if transportation, communications, and/or public utilities & $\begin{array}{c}0.084 \\
(0.277)\end{array}$ & $\begin{array}{c}0.083 \\
(0.275)\end{array}$ & $\begin{array}{c}0.119 \\
(0.325)\end{array}$ \\
\hline Financial industry & $=1$ if finance, insurance, or real estate industry & $\begin{array}{c}0.075 \\
(0.263)\end{array}$ & $\begin{array}{c}0.077 \\
(0.267)\end{array}$ & $\begin{array}{c}0.007 \\
(0.081)\end{array}$ \\
\hline $\begin{array}{l}\text { Entertainment and recreation } \\
\text { industry }\end{array}$ & $=1$ if entertainment and recreation industry & $\begin{array}{c}0.01 \\
(0.098)\end{array}$ & $\begin{array}{c}0.009 \\
(0.095)\end{array}$ & $\begin{array}{c}0.026 \\
(0.161)\end{array}$ \\
\hline Professional and related industry & $\begin{array}{l}=1 \text { if professional services including medical, social, and } \\
\text { educational services }\end{array}$ & $\begin{array}{c}0.281 \\
(0.449)\end{array}$ & $\begin{array}{c}0.284 \\
(0.451)\end{array}$ & $\begin{array}{c}0.192 \\
(0.395)\end{array}$ \\
\hline Public administration industry & $=1$ if public administration industry & $\begin{array}{c}0.064 \\
(0.246)\end{array}$ & $\begin{array}{c}0.065 \\
(0.246)\end{array}$ & $\begin{array}{c}0.06 \\
(0.238)\end{array}$ \\
\hline
\end{tabular}


TABLe 1: Continued.

\begin{tabular}{|c|c|c|c|c|}
\hline Variable & Description & All & Day & Night \\
\hline $\begin{array}{l}\text { Executive and managerial } \\
\text { occupation }\end{array}$ & $=1$ if executive, administrative, or managerial occupation & $\begin{array}{c}0.182 \\
(0.386)\end{array}$ & $\begin{array}{c}0.187 \\
(0.390)\end{array}$ & $\begin{array}{l}0.046 \\
(0.211)\end{array}$ \\
\hline Professional/specialty occupation & $=1$ if professional or specialty occupation & $\begin{array}{c}0.185 \\
(0.388)\end{array}$ & $\begin{array}{c}0.187 \\
(0.390)\end{array}$ & $\begin{array}{c}0.113 \\
(0.317)\end{array}$ \\
\hline Technical occupation & $=1$ if technician or related support occupation & $\begin{array}{c}0.036 \\
(0.187)\end{array}$ & $\begin{array}{c}0.037 \\
(0.188)\end{array}$ & $\begin{array}{c}0.026 \\
(0.161)\end{array}$ \\
\hline Sales occupation & $=1$ if sales occupation & $\begin{array}{c}0.09 \\
(0.287)\end{array}$ & $\begin{array}{c}0.092 \\
(0.289)\end{array}$ & $\begin{array}{l}0.046 \\
(0.211)\end{array}$ \\
\hline Clerical occupation & $=1$ if administrative support or clerical occupation & $\begin{array}{c}0.172 \\
(0.377)\end{array}$ & $\begin{array}{c}0.175 \\
(0.380)\end{array}$ & $\begin{array}{c}0.099 \\
(0.300)\end{array}$ \\
\hline Protective services occupation & $=1$ if protective services occupation & $\begin{array}{c}0.017 \\
(0.128)\end{array}$ & $\begin{array}{c}0.013 \\
(0.115)\end{array}$ & $\begin{array}{c}0.099 \\
(0.300)\end{array}$ \\
\hline Craft occupation & $=1$ if precision production, craft, and/or repair & $\begin{array}{c}0.12 \\
(0.326)\end{array}$ & $\begin{array}{c}0.12 \\
(0.325)\end{array}$ & $\begin{array}{c}0.139 \\
(0.347)\end{array}$ \\
\hline Operator occupation & $=1$ if machine operator, assembler, or inspector occupation & $\begin{array}{c}0.056 \\
(0.229)\end{array}$ & $\begin{array}{c}0.052 \\
(0.222)\end{array}$ & $\begin{array}{c}0.152 \\
(0.361)\end{array}$ \\
\hline Transport occupation & $=1$ if transportation or material moving occupation & $\begin{array}{c}0.041 \\
(0.197)\end{array}$ & $\begin{array}{c}0.039 \\
(0.195)\end{array}$ & $\begin{array}{c}0.073 \\
(0.261)\end{array}$ \\
\hline Laborer occupation & $\begin{array}{l}=1 \text { if handler, equipment cleaner, helper, or laborer } \\
\text { occupation }\end{array}$ & $\begin{array}{c}0.025 \\
(0.155)\end{array}$ & $\begin{array}{c}0.023 \\
(0.150)\end{array}$ & $\begin{array}{c}0.066 \\
(0.250)\end{array}$ \\
\hline Unemployment rate & Unemployment rate at labor market of current residence & $\begin{array}{c}4.03 \\
(1.630)\end{array}$ & $\begin{array}{c}4.029 \\
(1.625)\end{array}$ & $\begin{array}{c}4.081 \\
(1.760)\end{array}$ \\
\hline Coincident index & $\begin{array}{l}\text { Percentage change in state coincident index from April } 2001 \\
\text { to May } 2001\end{array}$ & $\begin{array}{c}0.639 \\
(1.994)\end{array}$ & $\begin{array}{c}0.64 \\
(1.983)\end{array}$ & $\begin{array}{c}0.614 \\
(2.279)\end{array}$ \\
\hline Observations & & 4035 & 3884 & 151 \\
\hline
\end{tabular}

Source: author's calculations, CPS May 2001 [13], sample used in regressions. Standard deviations are in parentheses.

used in the analysis is produced for each of the 50 states by the Federal Reserve Bank of Philadelphia, with the indices calculated monthly [20]. The state coincident index provides information about the current state of the economy and includes four state-level indicators: nonfarm payroll employment, average hours worked in manufacturing, the unemployment rate, and wage and salary disbursements deflated by the consumer price index. In the regression analysis, we use the one month percentage change in the state coincident index from April 2001 to May 2001 as an indicator of accelerating or declining economic activity.

Industry and Occupation. The 2001 CPS categorizes a worker's industry and occupation according to the 1980 Census Bureau classifications. Approximately 30 percent of night shift workers in the sample are employed in manufacturing industries (both durable and nondurable), 18 percent are employed in retail trade, and 19 percent are employed in professional and related services industries such as medical and educational service industries. The industries least populated by night shift work are agriculture, forestry, fishing, mining, construction, finance, insurance and real estate, and entertainment and recreation services. Approximately 29 percent of night shift workers are employed as machine operators, assemblers, and inspectors, movers, helpers, or laborers, with approximately 21 percent employed in service occupations.

Exclusion Restrictions. For identification purposes, children present, multiple jobs, and shift rate are included in the selection equation only. The presence of children may impact workers' decisions to work at night since workers may alter their work schedule to align with their children's needs. Following Kostiuk [3], multiple jobs are included as an instrument in the selection equation. The presence of multiple jobs indicates that an individual's work scheduling preferences are secondary to employment opportunities and income needs; thus these individuals may be more likely to select night shift work regardless of the inconvenience associated with this work schedule. (Individuals in the dataset are classified as either night or day workers based on the shift worked at their primary job (at which they are employed for a minimum of thirty hours per week). The wage used as the dependent variable in the regressions is the hourly wage at the individual's primary job. An individual whose primary job is a "day" job may, for example, have a second job during which they are employed at night. This individual, however, is not counted as a "night" worker in the sample since their 
primary job takes place during the day.) Following Kostiuk [3] and Lanfranchi et al. [4], the industry shift rate is included in the selection equation. The shift rate variable is calculated as the proportion of civilian night shift workers in the full CPS 2001 sample in each of 234 detailed industry categories.

\section{Results}

The ESR model is evaluated using two measures of local economic conditions: the local unemployment rate and the one month percentage change in the state coincident index. The regression results are first discussed, followed by an analysis of the computed interaction effects and a discussion of shift differentials.

\subsection{Endogenous Switching Regression Results}

4.1.1. Reduced Form of the Selection Equation. Selected coefficients from maximum likelihood estimation of the reduced form of the selection equation (10) with corresponding standard errors are reported in column 1 of Table 2. Regressors in the reduced form selection equation include the explanatory variables used in the individual wage equations, three exclusion restrictions, children present, multiple jobs, and industry shift rate, and a measure of local economic conditions. Both the unemployment rate and the coincident index are insignificant predictors of shift choice. The presence of children does not significantly impact the likelihood of working at night, nor does holding multiple jobs; however, working in industries that employ larger percentages of shift workers has a positive and significant impact on shift choice. Other positive and significant predictors of shift choice are years of schooling and union membership as well as working in certain occupations and industries. We will return to Table 2 to discuss the results from the structural form probit after discussing the results of the wage equations.

4.1.2. Day and Night Wage Equations. The reduced form probit results are used to control for self-selection into night shift work in the estimation of day and night worker wage equations with the results shown in Table 3 . The main variables of interest, the local economic condition variables, and the selection terms are shown in the upper rows of the table. The unemployment rate and the coincident index are insignificant predictors of both day and night worker wages. The selection term coefficients are estimates of the covariance between the error terms in the individual wage equations and the error term in the reduced form of the selection equation. In both the model with the unemployment rate and the model with the coincident index, the coefficient on the selection term for night workers is positive, indicating a positive correlation between the error term of the night shift equation and the error term in the reduced form of the selection equation. This coefficient is, however, insignificant which fails to indicate the presence of selection bias. This finding is consistent with Kostiuk, who also finds no evidence of significant selection into shift work. The selection term coefficient for day workers is negative and significant, which indicates positive selection into day work. Thus, those choosing to work during the day have higher expected earnings from day work and are better off not selecting night shift work. The significance of the coefficient confirms the presence of selection bias, underscoring the need to correct for self-selection.

Examining the other variables included in the wage equations provides an interesting comparison between night and day workers. (Following Maddala [9], we test whether we should have instead pooled the data on day and night workers by comparing the results obtained from the ESR model to the results obtained from maximum likelihood estimates of a treatment effects model of the form $\log W_{i}=$ $\alpha+\beta_{1} X_{i}+\beta_{2}$ nshift $_{i}+\beta_{3} L E C_{i}+\varepsilon_{i}$. The reduced form of the selection equation for night shift work is provided by (9). The log-likelihoods from the switching regression and treatment effects models are compared through a likelihood ratio test, with results of the LR test shown in the last row of Table 3. The significance of the LR statistic confirms that it was appropriate to assume that the returns to the coefficients for day and night workers are significantly different and the ESR model is appropriate.) Day workers experience significant, positive returns to experience and union membership while there are no significant differences in returns to these characteristics for night shift workers. Married day shift workers earn significantly higher wages than nonmarried individuals who work during the day. Nonwhite night shift workers earn significantly lower wages than white night shift workers. Female workers receive significantly lower wages than their male counterparts, regardless of whether they work during the day or at night. Those night workers in the transportation and public administration industries earn significantly more than night workers employed in the base group of manufacturing industries. Relative to the industry variables, greater differences in returns are experienced for night workers when evaluating the impact of their occupation on wages. Positive and significant differences in wages are prevalent for night workers in executive, professional, technical, clerical, craft, and operator occupations when compared to the base group of service occupations.

4.1.3. Structural Form of the Selection Equation. We now return to Table 2 to consider the results from estimation of the structural equation (5). These results are displayed in column 2 for ease of comparison with the reduced form results in column 1 . The main parameters of interest are the local economic condition variables (unemployment rate and coincident index) and the wage differential variables. We turn first to determining the impact of local economic conditions on shift choice. The coefficients on the unemployment rate and the coincident index remain insignificant in the estimation of the structural form. The results fail to indicate a significant impact of local economic conditions on shift choice. The other parameter of interest is the coefficient on the wage differential, which is computed by first using the results of the wage regressions for day and night workers (Table 3 ) to compute the conditional expected night shift premium for each individual. The expected wage premium is then used in the estimation of the structural probit (5). The 
TABLE 2: Reduced and structural probit results.

\begin{tabular}{|c|c|c|}
\hline Variable & $\begin{array}{l}\text { Reduced form } \\
\text { (1) }\end{array}$ & $\begin{array}{c}\text { Structural form } \\
\text { (2) }\end{array}$ \\
\hline $\begin{array}{l}\text { Wage differential } \\
\text { (model using unemployment rate) }\end{array}$ & & $\begin{array}{l}0.695^{* *} \\
(0.310)\end{array}$ \\
\hline $\begin{array}{l}\text { Wage differential } \\
\text { (model using coincident index) }\end{array}$ & & $\begin{array}{l}0.670^{* *} \\
(0.289)\end{array}$ \\
\hline $\begin{array}{l}\text { Unemployment rate } \\
\text { (model using unemployment rate) }\end{array}$ & $\begin{array}{l}-0.001 \\
(0.027)\end{array}$ & $\begin{array}{c}0.007 \\
(0.025)\end{array}$ \\
\hline $\begin{array}{l}\text { Coincident index } \\
\text { (model using coincident index) }\end{array}$ & $\begin{array}{c}0.006 \\
(0.022)\end{array}$ & $\begin{array}{c}0.006 \\
(0.022)\end{array}$ \\
\hline Industry shift rate & $\begin{array}{r}0.117^{* * *} \\
(0.010)\end{array}$ & $\begin{array}{l}0.117^{* * *} \\
(0.009)\end{array}$ \\
\hline Multiple jobs & $\begin{array}{c}0.129 \\
(0.157)\end{array}$ & $\begin{array}{l}0.240 \\
(0.151)\end{array}$ \\
\hline Children present & $\begin{array}{c}0.074 \\
(0.103)\end{array}$ & $\begin{array}{c}0.067 \\
(0.099)\end{array}$ \\
\hline Years of school & $\begin{array}{c}0.462^{* * *} \\
(0.177)\end{array}$ & $\begin{array}{c}0.039 \\
(0.028)\end{array}$ \\
\hline Years of school squared & $\begin{array}{c}-0.019^{* * *} \\
(0.007)\end{array}$ & \\
\hline Experience & $\begin{array}{c}0.029 \\
(0.043)\end{array}$ & $\begin{array}{l}-0.002 \\
(0.005)\end{array}$ \\
\hline Experience squared & $\begin{array}{l}-0.003 \\
(0.002)\end{array}$ & \\
\hline Union & $\begin{array}{l}0.186^{*} \\
(0.114)\end{array}$ & $\begin{array}{c}0.145 \\
(0.111)\end{array}$ \\
\hline Nonwhite & $\begin{array}{c}0.168 \\
(0.121)\end{array}$ & $\begin{array}{c}0.188 \\
(0.125)\end{array}$ \\
\hline Female & $\begin{array}{l}0.028 \\
(0.101)\end{array}$ & $\begin{array}{r}-0.069 \\
(0.110)\end{array}$ \\
\hline Married & $\begin{array}{l}-0.145 \\
(0.114)\end{array}$ & $\begin{array}{l}-0.128 \\
(0.118)\end{array}$ \\
\hline Wholesale trade industry & $\begin{array}{c}0.147 \\
(0.273)\end{array}$ & $\begin{array}{l}-0.193 \\
(0.282)\end{array}$ \\
\hline Retail trade industry & $\begin{array}{c}0.779^{* * *} \\
(0.151)\end{array}$ & $\begin{array}{c}0.535^{* * *} \\
(0.146)\end{array}$ \\
\hline Transportation industry & $\begin{array}{c}0.215 \\
(0.164)\end{array}$ & $\begin{array}{c}0.015 \\
(0.172)\end{array}$ \\
\hline Financial industry & $\begin{array}{c}0.172 \\
(0.357)\end{array}$ & $\begin{array}{l}-0.107 \\
(0.360)\end{array}$ \\
\hline Entertainment and recreation industry & $\begin{array}{l}0.623^{* *} \\
(0.324)\end{array}$ & $\begin{array}{l}0.544^{* *} \\
(0.272)\end{array}$ \\
\hline Professional and related industry & $\begin{array}{c}0.228 \\
(0.157)\end{array}$ & $\begin{array}{l}-0.061 \\
(0.131)\end{array}$ \\
\hline Public administration industry & $\begin{array}{c}0.173 \\
(0.237)\end{array}$ & $\begin{array}{l}-0.242 \\
(0.251)\end{array}$ \\
\hline Executive and managerial occupation & $\begin{array}{c}-0.764^{* * *} \\
(0.207)\end{array}$ & $\begin{array}{c}-0.645^{* * *} \\
(0.215)\end{array}$ \\
\hline Professional/specialty occupation & $\begin{array}{l}-0.219 \\
(0.190)\end{array}$ & $\begin{array}{c}-0.456^{*} \\
(0.190)\end{array}$ \\
\hline
\end{tabular}


TABLE 2: Continued.

\begin{tabular}{|c|c|c|}
\hline Variable & $\begin{array}{l}\text { Reduced form } \\
\text { (1) }\end{array}$ & $\begin{array}{c}\text { Structural form } \\
\text { (2) }\end{array}$ \\
\hline \multirow{2}{*}{ Technical occupation } & -0.363 & -0.306 \\
\hline & $(0.259)$ & $(0.262)$ \\
\hline \multirow{2}{*}{ Sales occupation } & $-0.907^{* * *}$ & $-0.412^{*}$ \\
\hline & $(0.228)$ & $(0.239)$ \\
\hline \multirow{2}{*}{ Clerical occupation } & $-0.499^{* *}$ & $-0.538^{* * *}$ \\
\hline & $(0.183)$ & $(0.178)$ \\
\hline \multirow{2}{*}{ Protective services occupation } & $0.605^{* *}$ & $0.619^{* *}$ \\
\hline & $(0.248)$ & $(0.266)$ \\
\hline \multirow{2}{*}{ Craft occupation } & -0.069 & $-0.315^{*}$ \\
\hline & $(0.182)$ & $(0.190)$ \\
\hline \multirow{2}{*}{ Operator occupation } & 0.262 & 0.018 \\
\hline & $(0.191)$ & $(0.196)$ \\
\hline \multirow{2}{*}{ Transport occupation } & 0.018 & 0.053 \\
\hline & $(0.220)$ & $(0.218)$ \\
\hline \multirow{2}{*}{ Laborer occupation } & 0.140 & -0.033 \\
\hline & $(0.232)$ & $(0.220)$ \\
\hline \multirow{2}{*}{ Constant } & $-4.770^{* * *}$ & $-2.495^{* *}$ \\
\hline & $(1.233)$ & $(0.436)$ \\
\hline Observations & & 4035 \\
\hline Log-likelihood & -2401.119 & -500.866 \\
\hline
\end{tabular}

Levels of significance: ${ }^{* * *} 1 \%,{ }^{* *} 5 \%$, and ${ }^{*} 10 \%{ }^{*}$ The ESR model is first estimated using the one month percentage change in the coincident index as the indicator of local economic conditions. The model is then reestimated using the unemployment rate as the indicator of local economic conditions. Due to the similarity of coefficients for the education, experience, gender, marital status, union membership, race, industry, and occupation variables, only the regression results from the model using the one month percentage change in the coincident index as the indicator of local economic conditions are shown for these variables. Coefficients for these variables using the unemployment rate are available upon request. Standard errors are shown in parentheses. Other controls include experience cubed, region of residence, and an indicator for MSA residence.

wage differential is a statistically significant predictor of shift choice in both specifications of the model. The sign of these coefficients indicates that rising wage differentials for night shift work make individuals more likely to choose night shift work. This is an important result, providing evidence that individuals consider the size of the shift premium when deciding whether to work at night. This result suggests that night shift choice is a result of shift differentials, not preferences for night shift work.

The results for other variables included in the structural equation provide evidence of the factors influencing workers as they make choices regarding work hours after controlling for the wage differential. The industry shift rate remains significant in the structural equation, indicating that this variable still plays an important role in shift choice regardless of the shift differential that is offered. The inclusion of the wage differential causes the coefficient on years of school and union to become statistically insignificant. This result indicates that, after controlling for the wage differential, education and union membership no longer impact shift choice; thus, much of the impact of education and union membership on shift choice occurs through their impact on wages. Several occupation and industry variables continue to significantly impact shift choice, most likely because an individual's work schedule is often dictated by their employer or job responsibilities.
In summary, the ESR model results indicate that shift differentials significantly impact an individual's decision to work at night but do not provide evidence that local labor market conditions significantly impact shift choice. The model indicates the presence of selection bias, confirming the need to correct for self-selection into shift work.

4.2. Interaction Effects. An important conclusion of this paper is that the shift differential is found to be a significant predictor of shift choice. To further investigate the impact of the shift differential on shift choice, we present a new method of analyzing interaction effects in the context of the ESR model. The ESR results were used to estimate interaction effects between the shift differential and the two measures of local economic conditions. To investigate possible interaction effects, we consider the probability of selecting night shift work conditional on the shift differential, local economic conditions, and the observed exogenous covariates, as outlined in Section 2.3. We estimate the effect of changes in the shift differential on the selection probability (12) under different local economic conditions. As an example of how interaction effects may be analyzed in the context of this model, Table 4 presents the results of this analysis using the one month percentage change in the coincident index as the measure of local economic conditions. The estimated interaction effects are small which indicates that the local economic conditions 
TABLE 3: Night and day wage equations.

\begin{tabular}{|c|c|c|}
\hline Variable & $\begin{array}{l}\text { Night worker } \\
\text { (1) }\end{array}$ & $\begin{array}{l}\text { Day worker } \\
\text { (2) }\end{array}$ \\
\hline Unemployment rate* & 0.005 & 0.000 \\
\hline (model using unemployment rate) & $(0.013)$ & $(0.004)$ \\
\hline Coincident index & 0.011 & -0.002 \\
\hline (model using coincident index) & $(0.010)$ & $(0.004)$ \\
\hline $\begin{array}{l}\text { Selection term } \\
\text { (model using unemployment rate) }\end{array}$ & 0.030 & $-0.231^{* * *}$ \\
\hline $\begin{array}{l}\text { Selection term } \\
\text { (model using coincident index) }\end{array}$ & 0.034 & $-0.231^{* * *}$ \\
\hline Years of school & $\begin{array}{l}0.169^{*} \\
(0.094)\end{array}$ & $\begin{array}{l}-0.014 \\
(0.015)\end{array}$ \\
\hline Years of school squared & $\begin{array}{l}-0.006^{*} \\
(0.004)\end{array}$ & $\begin{array}{c}0.004^{* * *} \\
(0.001)\end{array}$ \\
\hline Experience & $\begin{array}{l}-0.019 \\
(0.023)\end{array}$ & $\begin{array}{c}0.031^{* * *} \\
(0.007)\end{array}$ \\
\hline Experience squared & $\begin{array}{c}0.001 \\
(0.001)\end{array}$ & $\begin{array}{c}-0.001^{* *} \\
(0.000)\end{array}$ \\
\hline Union & $\begin{array}{c}0.090 \\
(0.060)\end{array}$ & $\begin{array}{c}0.127^{* * *} \\
(0.019)\end{array}$ \\
\hline Nonwhite & $\begin{array}{l}-0.105^{*} \\
(0.058)\end{array}$ & $\begin{array}{l}-0.026 \\
(0.020)\end{array}$ \\
\hline Female & $\begin{array}{c}-0.129^{* *} \\
(0.052)\end{array}$ & $\begin{array}{c}-0.230^{* * *} \\
(0.016)\end{array}$ \\
\hline Married & $\begin{array}{c}0.077 \\
(0.060)\end{array}$ & $\begin{array}{c}0.057^{* * *} \\
(0.190)\end{array}$ \\
\hline Wholesale trade industry & $\begin{array}{l}0.311^{*} \\
(0.175)\end{array}$ & $\begin{array}{c}-0.121^{* * *} \\
(0.034)\end{array}$ \\
\hline Retail trade industry & $\begin{array}{l}-0.011 \\
(0.091)\end{array}$ & $\begin{array}{c}-0.236^{* * *} \\
(0.026)\end{array}$ \\
\hline Transportation industry & $\begin{array}{c}0.268^{* * *} \\
(0.089)\end{array}$ & $\begin{array}{l}0.061^{* *} \\
(0.026)\end{array}$ \\
\hline Financial industry & $\begin{array}{c}0.172 \\
(0.285)\end{array}$ & $\begin{array}{c}0.017 \\
(0.027)\end{array}$ \\
\hline Entertainment and recreation industry & $\begin{array}{l}-0.086 \\
(0.153)\end{array}$ & $\begin{array}{c}-0.205^{* * *} \\
(0.069)\end{array}$ \\
\hline Professional and related industry & $\begin{array}{c}0.005 \\
(0.102)\end{array}$ & $\begin{array}{c}-0.180^{* * *} \\
(0.020)\end{array}$ \\
\hline Public administration industry & $\begin{array}{c}0.287^{* *} \\
(0.127)\end{array}$ & $\begin{array}{c}-0.053^{*} \\
(0.031)\end{array}$ \\
\hline Executive and managerial occupation & $\begin{array}{c}0.335^{* *} \\
(0.135)\end{array}$ & $\begin{array}{c}0.504^{* * *} \\
(0.030)\end{array}$ \\
\hline Professional/specialty occupation & $\begin{array}{c}0.744^{* * *} \\
(0.100)\end{array}$ & $\begin{array}{c}0.432^{* * *} \\
(0.032)\end{array}$ \\
\hline Technical occupation & $\begin{array}{c}0.358^{* *} \\
(0.155)\end{array}$ & $\begin{array}{c}0.410^{* * *} \\
(0.042)\end{array}$ \\
\hline Sales occupation & $\begin{array}{l}-0.026 \\
(0.143)\end{array}$ & $\begin{array}{c}0.426^{* * *} \\
(0.035)\end{array}$ \\
\hline Clerical occupation & $\begin{array}{c}0.230^{* *} \\
(0.116)\end{array}$ & $\begin{array}{c}0.218^{* * *} \\
(0.030)\end{array}$ \\
\hline
\end{tabular}


TABLE 3: Continued.

\begin{tabular}{|c|c|c|}
\hline Variable & $\begin{array}{c}\text { Night worker } \\
\text { (1) }\end{array}$ & $\begin{array}{c}\text { Day worker } \\
\text { (2) }\end{array}$ \\
\hline \multirow{2}{*}{ Protective services occupation } & 0.150 & $0.146^{* *}$ \\
\hline & $(0.117)$ & $(0.064)$ \\
\hline \multirow{2}{*}{ Craft occupation } & $0.491^{* * *}$ & $0.261^{* * *}$ \\
\hline & $(0.111)$ & $(0.032)$ \\
\hline \multirow{2}{*}{ Operator occupation } & $0.223^{* *}$ & -0.001 \\
\hline & $(0.107)$ & $(0.038)$ \\
\hline \multirow{2}{*}{ Transport occupation } & 0.042 & $0.110^{* * *}$ \\
\hline & $(0.127)$ & $(0.042)$ \\
\hline \multirow{2}{*}{ Laborer occupation } & 0.078 & -0.046 \\
\hline & $(0.122)$ & $(0.049)$ \\
\hline \multirow{2}{*}{ Constant } & 1.023 & $1.681^{* * *}$ \\
\hline & $(0.672)$ & $(0.110)$ \\
\hline Observations & & 4035 \\
\hline Log-likelihood & & -2401.119 \\
\hline LR test of independent equations & & $161.19^{* * *}$ \\
\hline
\end{tabular}

Levels of significance: ${ }^{* * *} 1 \%,{ }^{* *} 5 \%$, and ${ }^{*} 10 \%{ }^{*}$ The ESR model is first estimated using the one month percentage change in the coincident index as the indicator of local economic conditions. The model is then reestimated using the unemployment rate as the indicator of local economic conditions. Due to the similarity of coefficients for the education, experience, gender, marital status, union membership, race, industry, and occupation variables, only the regression results from the model using the one month percentage change in the coincident index as the indicator of local economic conditions are shown for these variables. Coefficients for these variables using the unemployment rate are available upon request. Standard errors are shown in parentheses. Other controls include experience cubed, region of residence, and an indicator for MSA residence.

TABLE 4: Interaction effects using the coincident index.

\begin{tabular}{|c|c|c|c|c|c|c|c|c|c|c|c|}
\hline \multirow{4}{*}{ Index } & \multirow{4}{*}{ Cell } & \multicolumn{10}{|c|}{ Log wage differential } \\
\hline & & \multicolumn{2}{|c|}{-0.56070} & \multicolumn{2}{|c|}{-0.32671} & \multicolumn{2}{|c|}{-0.13668} & \multicolumn{2}{|c|}{0.07415} & \multicolumn{2}{|c|}{0.20970} \\
\hline & & Lower & Upper & Lower & Upper & Lower & Upper & Lower & Upper & Lower & Upper \\
\hline & & \multicolumn{2}{|c|}{1} & \multicolumn{2}{|c|}{2} & \multicolumn{2}{|c|}{3} & \multicolumn{2}{|c|}{4} & \multicolumn{2}{|c|}{5} \\
\hline-1.73 & \multirow{2}{*}{ A } & 0.001075 & 0.014638 & 0.002019 & 0.020283 & 0.003144 & 0.026160 & 0.004894 & 0.034315 & 0.006394 & 0.040611 \\
\hline Average* & & \multicolumn{2}{|c|}{0.007856} & \multicolumn{2}{|c|}{0.011151} & \multicolumn{2}{|c|}{0.014652} & \multicolumn{2}{|c|}{0.019605} & \multicolumn{2}{|c|}{0.023503} \\
\hline-0.31 & \multirow{2}{*}{ B } & 0.001115 & 0.014902 & 0.002082 & 0.020634 & 0.003232 & 0.026595 & 0.005019 & 0.034863 & 0.006552 & 0.041241 \\
\hline Average & & \multicolumn{2}{|c|}{0.008009} & \multicolumn{2}{|c|}{0.011358} & \multicolumn{2}{|c|}{0.014914} & \multicolumn{2}{|c|}{0.019941} & \multicolumn{2}{|c|}{0.023897} \\
\hline 0.64 & \multirow{2}{*}{$\mathrm{C}$} & 0.001143 & 0.015082 & 0.002126 & 0.020871 & 0.003292 & 0.026890 & 0.005105 & 0.035234 & 0.006660 & 0.041667 \\
\hline Average & & \multicolumn{2}{|c|}{0.008112} & \multicolumn{2}{|c|}{0.011498} & \multicolumn{2}{|c|}{0.015091} & \multicolumn{2}{|c|}{0.020169} & \multicolumn{2}{|c|}{0.024163} \\
\hline 1.34 & \multirow{2}{*}{$\mathrm{D}$} & 0.001163 & 0.015215 & 0.002158 & 0.021048 & 0.003337 & 0.027109 & 0.005168 & 0.035509 & 0.006740 & 0.041983 \\
\hline Average & & \multicolumn{2}{|c|}{0.008189} & \multicolumn{2}{|c|}{0.011603} & \multicolumn{2}{|c|}{0.015223} & \multicolumn{2}{|c|}{0.020338} & 0.02 & 362 \\
\hline 2.02 & $\mathrm{~F}$ & 0.001184 & 0.015345 & 0.002190 & 0.021220 & 0.003381 & 0.027324 & 0.005231 & 0.035778 & 0.006819 & 0.042292 \\
\hline Average & $\mathrm{E}$ & 0.00 & 264 & 0.01 & 705 & 0.01 & 352 & 0.02 & 504 & 0.02 & 556 \\
\hline
\end{tabular}

This table presents lower and upper bounds on the probability of working the night shift. The bounds on the probability are computed for each combination of the log wage differential and the one month percentage change in the leading index. For example, the lower bound for the log wage differential and leading index combination $\mathrm{Al}$ is 0.001075 while the upper bound is 0.014638 . ${ }^{*}$ The average of the lower and upper bounds is reported below each combination. For example, the average probability for combination $\mathrm{A} 1$ is 0.007856 . From left to right, the values of the log wage differential indicate the 10th percentile, 25 th percentile, mean, 75th percentile, and 90th percentile of the predicted log wage differential. From top to bottom, the values of the percentage change in the leading index indicate the 10th percentile, 25th percentile, mean, 75th percentile, and 90th percentile.

employed in this model have a small impact on the role of the shift differential in shift choice. (The results in this section are discussed for the regression results using the coincident index as the measure of local economic conditions. These small effects are also found when the model is estimated using the local unemployment rate as the measure of local economic conditions.)
Table 4 presents the lower and upper bounds of the selection probability for different combinations of percentile values of the log wage differential and the one month percentage change in the coincident index. As a method of interpreting the bounds, the midpoint of the lower and upper bounds is presented below each interval. The intervals in each row, represented by letters $\mathrm{A}-\mathrm{E}$, indicate how changes in the 
TABLE 5: Average shift differentials by worker characteristic.

\begin{tabular}{lc}
\hline & Shift differential \\
\hline Full sample & -0.136 \\
Union & -0.070 \\
Nonunion & -0.149 \\
Male & -0.202 \\
Female & -0.069 \\
Married & -0.150 \\
Nonmarried & -0.060 \\
White & -0.128 \\
Nonwhite & -0.191 \\
Non-high school graduate & -0.020 \\
High school graduate & -0.008 \\
Associate's degree & -0.081 \\
College graduate & -0.336 \\
\hline
\end{tabular}

Source: author's calculations, May 2001 CPS [13]. The shift differential is measured in log points and is calculated as the difference between the log night hourly wage and the day log hourly wage. The differentials in the table are the predicted shift premiums averaged for all workers with those characteristics. High school graduates are those with a minimum of twelve years of school. Due to the similarity of results for the model using the coincident index and the unemployment rate, only the differentials calculated using the coincident index are shown.

shift differential affect the selection probability for a given level of the one month percentage change in the coincident index. For example, one can compare interval A3 to interval A4 to see how a rise in the log wage differential from -0.13668 to 0.07415 impacts shift selection given a one-month percentage change in the coincident index of -1.73 . The intervals in each of the columns 1-5 indicate how changes in the one month percentage change in the coincident index impact the selection probability for a given log wage differential. For example, one can compare interval A3 to interval B3 to see how a rise in the percentage change in the coincident index from -1.73 to -0.31 impacts shift selection given a log wage differential of -0.13668 . Consequently, comparing intervals across two columns for two different rows reveals how the impact of changing log wage differentials varies for two different values of the percentage change in the coincident index, while comparing intervals across two rows for two different columns reveals how changing values of the percentage change in the coincident index varies for two different log wage differentials. This method will be used to analyze possible interaction effects with examples provided in the following pages.

Examining the rows in Table 4 indicates that, for a given value of the percentage change in the coincident index, increases in the wage differential for night shift work lead to a higher probability of selecting night shift work. Examining the columns indicates that, for a given wage differential, increases in the percentage change in the coincident index lead to a higher average probability of night shift selection. Intervals are next compared across two rows for two columns to determine interaction effects, which can be considered for many different combinations of changes in the wage differential and changes in the coincident index. As an example of how Table 4 can be used to determine interaction effects for various wage differentials and values of the one-month percentage change in the coincident index, we compare intervals $\mathrm{A} 3$ and $\mathrm{A} 4$ and $\mathrm{E} 3$ and $\mathrm{E} 4$ in three steps as follows.

Step 1 (compare results for intervals A3 and A4). Interval A3 has an average value of approximately $1.46 \%$ while interval A4 has an average value of approximately $1.96 \%$. Thus, for a one month percentage change in the coincident index of -1.73 , increasing the log wage differential from approximately -0.13668 to 0.07415 leads to an increase in the average selection probability of approximately $0.50 \%$.

Step 2 (compare results for intervals E3 and E4). Interval $\mathrm{E} 3$ has an average value of $1.54 \%$ while interval $\mathrm{E} 4$ has an average value of $2.05 \%$. Thus, for a one month percentage change in the coincident index of 2.02, increasing the log wage differential from approximately -0.13668 to 0.07415 leads to an increase in the average selection probability of approximately $0.52 \%$.

Step 3 (compare results for intervals A3 and A4 with results for intervals E3 and E4). When comparing the effect of increasing the log wage differential from -0.13668 to 0.07415 for a -1.73 percentage change in the coincident index to the effect of the same increase in the log wage differential for a 2.02 percentage change in the coincident index, the probability of night shift selection is $0.02 \%$ higher. Over these intervals, the interaction of the shift differential and the coincident index has a positive impact on the likelihood that an individual would select night shift work.

Positive interaction effects are obtained for various combinations of average probabilities in the rows and columns in Table 4. (Similar results are obtained when intervals are compared across two columns.) These interaction effects imply that as the percentage change in the coincident index rises an increase in the log wage differential has a larger impact on shift selection. In other words, in areas with recent improvements in economic conditions and, therefore, stronger economies, individuals are more likely to consider the size of the shift premium when determining whether to work at night. Conversely, in regions with weaker economies, individuals are less likely to consider the size of the shift differential when determining whether to work at night. This result provides evidence that compensating differentials for night shift work may be lower in weak economies.

4.3. Wage Differential Estimation. The shift differential is calculated for each individual in the sample and is included in the estimation of the structural equation to determine the impact of shift differentials on shift choice. Wage differentials are calculated as the difference between the log night hourly wage and the log day hourly wage for the ESR model. Table 5 presents the estimated wage differentials averaged over all workers with selected characteristics. The average shift differential for the full sample is $-13.6 \%$ with substantial variation among personal characteristics. The calculated shift differentials are negative, indicating that day workers earn higher 
wages on average than night shift workers in the sample. The diversity of the individuals in the sample coupled with diverse preferences for night shift work could explain these negative differentials for night work. The sample includes both male and female workers from different regional labor markets in every occupation and industry. It is possible that worker preferences, earnings potential, and labor supply decisions are so diverse that estimated shift differentials for night shift work are negative.

On average, night shift workers belonging to unions earn higher wage premiums than nonunion night shift workers. This result is consistent with the prevalence of collective bargaining agreements that ensure higher night wages for union workers. Female night shift workers are not penalized as much for working night shifts as male workers. Similar patterns are observed for nonmarried individuals, with nonmarried night shift workers receiving wages that are closer to those of their daytime counterparts. White individuals are not penalized as much for working night shifts as nonwhite individuals. Interestingly, workers with lower levels of education earn wages that are roughly equivalent to their daytime counterparts. This finding is consistent with Kostiuk [3], who notes that estimates of shift differentials indicate that those who are usually paid less in the labor market "earn consistently larger shift premiums." He posits that larger shift premiums occur for these workers because shift work jobs offer smaller pay changes for personal characteristics. His findings are consistent with our shift differential estimates for female, nonmarried, and less educated night shift workers who receive higher night shift differentials on average than male, married, and highly educated workers. The results for nonwhite workers, however, are inconsistent with this finding for our sample, suggesting that racial characteristics play an important role in predicting wages regardless of shift worked.

\section{Conclusion}

This paper questions the motivations for night shift work, the wages paid for night shift work, and the impact of labor market conditions upon work schedules by considering a variation of the theory of compensating differentials in which labor markets are weak. One innovation of our analysis is to include controls for local labor market conditions in the estimation of an endogenous switching regression model using CPS data. Another original contribution is a new method of estimating interaction effects in the ESR model.

The results emphasize the importance of correcting for self-selection through the use of the ESR model. Shift differentials have a statistically significant and positive impact on shift choice, indicating that individuals take the size of the wage premium offered for night shift work into account when selecting their work schedule. The local labor market conditions included in the analysis are insignificant predictors of shift choice. Using the estimation method outlined in Section 2.3, we find small interaction effects between the shift differential and local economic conditions in the structural selection equation. These interaction effects provide weak evidence that shift differentials have a smaller impact on shift choice when local economic conditions weaken; thus, compensating differentials for night shift work may be lower when local economies are weak. Estimated shift differentials indicate that night workers earn lower wages on average than day workers for the entire sample. Analyzing shift differentials by worker characteristics reveals that union members, females, non-married individuals, and non-college graduates receive night shift wages that are closer to their daytime counterparts.

This paper seeks to provide a better understanding of individuals as they make work schedule choices when local economies are weak, focusing on the sensitivity of the impact of shift differentials and local economic conditions on shift choice. The method of analyzing interaction effects in the context of the endogenous switching regression model developed in this paper could be applied to other studies employing ESR models. Future labor economics studies, for example, could explore whether the impact of wage differentials for other job characteristics on selection into a particular regime is sensitive to local economic conditions.

\section{Conflict of Interests}

The authors declare that there is no conflict of interests regarding the publication of this paper.

\section{References}

[1] A. Smith, The Wealth of Nations, Modern Library Editions, New York, NY, USA, 1776, reprinted 1937.

[2] S. Rosen, "The theory of equalizing differences," in Handbook of Labor Economics, O. Ashenfelter and R. Layard, Eds., vol. 1, pp. 641-692, Elsevier, Amsterdam, The Netherlands, 1986.

[3] P. Kostiuk, "Compensating differentials for shift work," Journal of Political Economy, vol. 98, no. 5, pp. 1055-1075, 1990.

[4] J. Lanfranchi, H. Ohlsson, and A. Skalli, "Compensating wage differentials and shift work preferences," Economics Letters, vol. 74, no. 3, pp. 393-398, 2002.

[5] E. J. Schumacher and B. T. Hirsch, "Compensating differentials and unmeasured ability in the labor market for nurses: why do hospitals pay more?" Industrial and Labor Relations Review, vol. 50, no. 4, pp. 557-579, 1997.

[6] S. Agnarsson, "Who works shifts? An analysis of the characteristics of male shift workers in Sweden," in Of Men and Machines: Essays in Applied Labour and Production Economics, Department of Economics, Goteborg University, Gothenburg, Sweden, 1998.

[7] R. DeBeaumont and C. Nsiah, "Unemployment and compensating wages: an analysis of shift work," Journal of Economics and Finance, vol. 34, pp. 142-149, 2010.

[8] K. A. Bender and H. Mridha, "The effect of local area unemployment on compensating wage differentials for injury risk," Southern Economic Journal, vol. 78, no. 2, pp. 287-307, 2011.

[9] G. S. Maddala, Limited Dependent and Qualitative Variables in Econometrics, Cambridge University Press, Cambridge, UK, 1983.

[10] L. Lee, "Unionism and wage rates: a simultaneous equations model with qualitative and limited dependent variables," International Economic Review, vol. 19, pp. 415-433, 1978. 
[11] M. Lokshin and Z. Sajaia, "Maximum likelihood estimation of endogenous switching regression models," The Stata Journal, vol. 4, no. 3, pp. 282-289, 2014.

[12] W. P. M. Vijverberg, "Measuring the unidentified parameter of the extended Roy model of selectivity," Journal of Econometrics, vol. 57, no. 1-3, pp. 69-89, 1993.

[13] Bureau of the Census, Current Population Survey, May 2001: Work Schedules and Work at Home Supplement, Bureau of the Census for the Bureau of Labor Statistics, Bureau of the Census, Washington, DC, USA, 2001.

[14] C. R. Bollinger and B. T. Hirsch, "Match bias from earnings imputation in the current population survey: the case of imperfect matching," Journal of Labor Economics, vol. 24, no. 3, pp. 483-519, 2006.

[15] M. D. Shapiro, "Cyclical productivity and the workweek of capital," The American Economic Review, vol. 83, no. 2, pp. 229233, 1993.

[16] J. Mayshar and G. Solon, "Shiftwork and the business cycle," American Economic Review, vol. 83, pp. 224-228, 1993.

[17] Y. Halevy and J. Nason, "Shiftwork and the real business cycle," Working Paper, University of British Columbia, Vancouver, Canada, 2002, http://econ.tau.ac.il/papers/faculty/shift04.pdf.

[18] K. L. Kliesen, "The 2001 recession: how was it different and what developments may have caused it?” Federal Reserve Bank of St. Louis Review, vol. 85, no. 5, pp. 23-38, 2003.

[19] R. Ilg, A Glance at Long-Term Unemployment in Recent Recessions, Issues in Labor Statistics, Summary no. 06-01, US Bureau of Labor Statistics, 2006.

[20] FRED (Federal Reserve Economic Data)-Federal Reserve Bank of St. Louis, Coincident Economic Activity Index for the United States, USPHCI, U.S. Department of Labor, Bureau of Labor Statistics, 2014, http://research.stlouisfed.org/fred2/ series/USPHCI. 

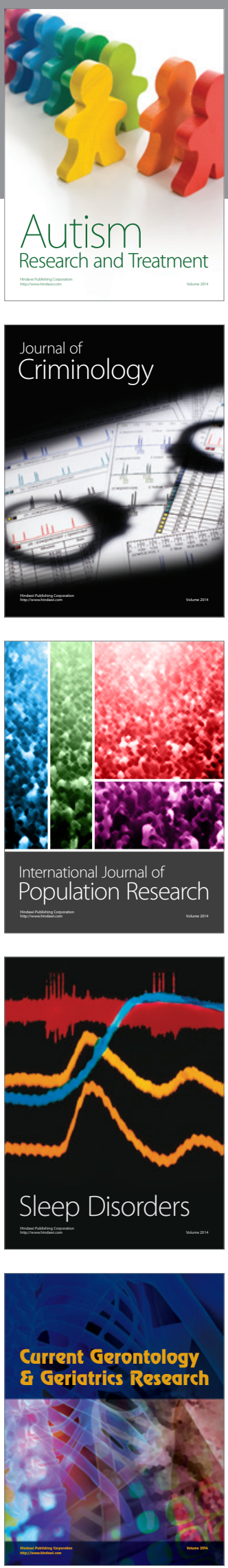
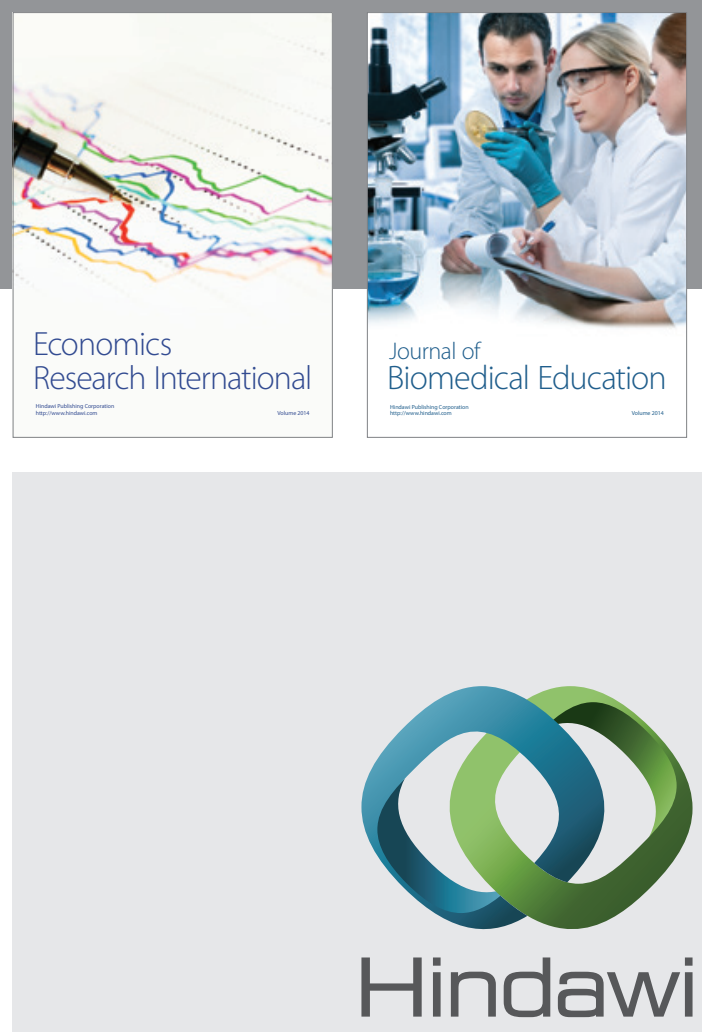

Submit your manuscripts at

http://www.hindawi.com
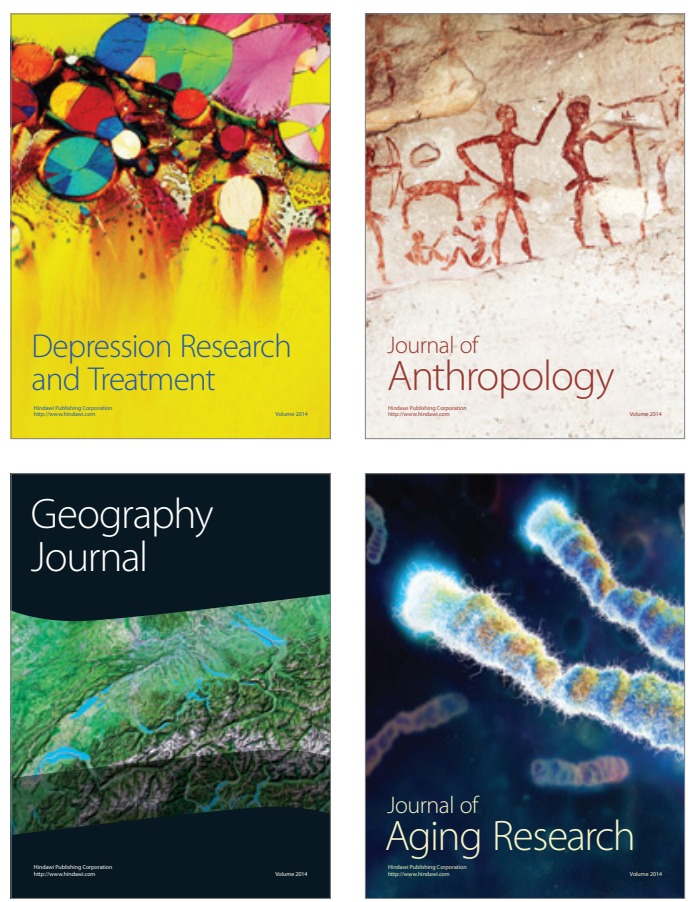
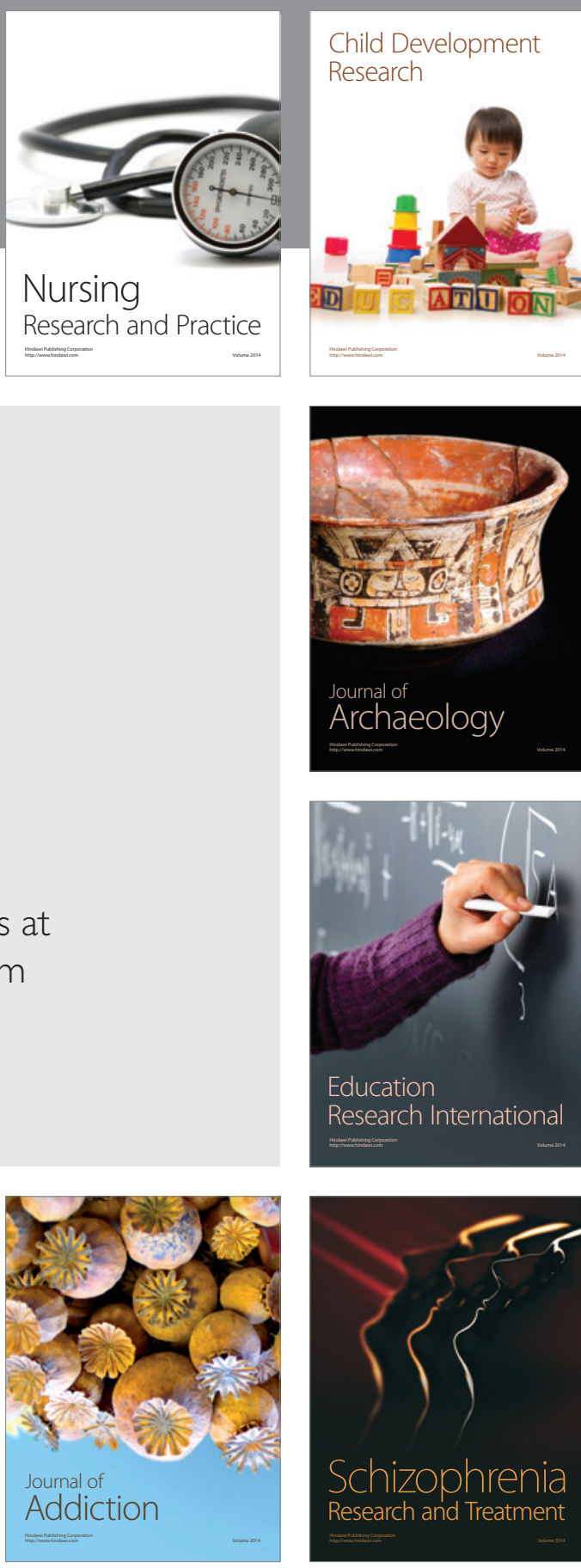

(D)
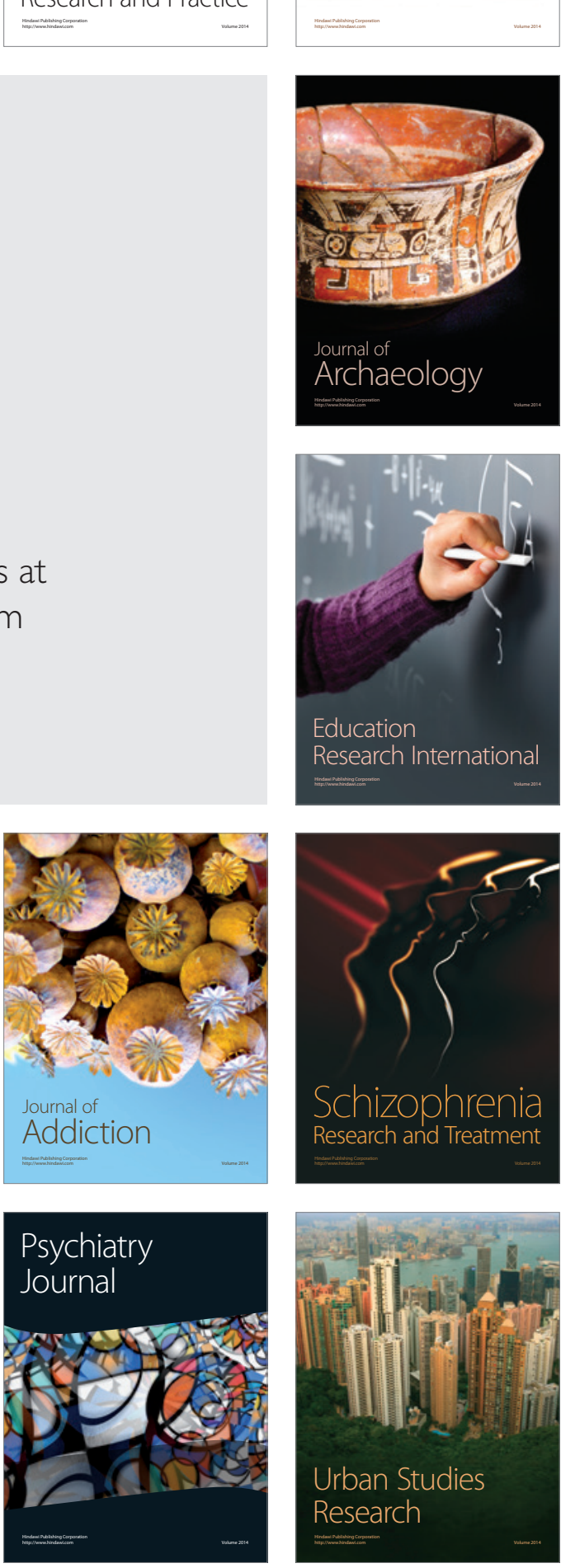